\title{
Evaluación de una pasta enriquecida con harina de Oxalis tuberosa en ratas Wistar con inducción del síndrome metabólico
}

\section{Evaluation of a Enriched Pasta with Flour of Oxalis tuberosa in Wistar Rats with Induction of Metabolic Syndrome}

\author{
Karla C Gress-Mogica, Norma Güemes Veraa ., Javier Piloni Martini., Sergio Soto Simental y Aurora Quintero- \\ Lira
}

\begin{abstract}
:
The current lifestyle can promote inadequate eating habits, causing serious health problems. Metabolic syndrome is considered an important form of cardiovascular risk and diabetes. The Oxalis, is an Andean tuber, with a high concentration of carbohydrates, essential amino acids, fiber, minerals and natural antioxidants such as in phenolic acids, flavones and anthocyanins. The aim of this study was to evaluate the nutritional properties of a enriched pasta with flour of Oxalis tuberosa and its effect on markers of the metabolic syndrome in biochemical and anthropometric parameters induced in Wistar rats. The total phenolic content and antioxidant activity were higher in pasta with Oxalis, as well as in protein and fiber. The induction group fed with the Oxalis pasta showed lower concentration in glucose, cholesterol and triglycerides in comparison to the other groups. These data suggest that the Oxalis tuberosa pasta may help reduce the pathological damage of metabolic syndrome in vivo.
\end{abstract}

Keywords:

antioxidants; fructose; Oxalis tuberosa; syndrome metabolic

Resumen:

El estilo de vida actual puede promover hábitos alimenticios inadecuados, causando problemas de salud. El síndrome metabólico se considera una forma importante de riesgo cardiovascular y diabetes. La Oxalis, es un tubérculo andino, con una alta concentración de carbohidratos, aminoácidos esenciales, fibra, minerales y antioxidantes naturales como ácidos fenólicos, flavonas y antocianinas. El objetivo de este estudio fue evaluar las propiedades nutricionales de una pasta enriquecida con harina de Oxalis tuberosa y su efecto sobre maracdores bioquimico y antropometricos inducido en ratas wistar. Los fenoles totales y la actividad antioxidante fueron mayores en la pasta con Oxalis, así como en proteína y fibra. El grupo inducción alimentado con la pasta Oxalis mostró menor concentración en glucosa, colesterol y triglicéridos en comparación a los otros grupos. Estos datos sugieren que la pasta de Oxalis tuberosa puede ayudar a reducir el daño patológico del síndrome metabólico in vivo.

\section{Palabras Clave:}

Cereal para desayuno, Oxalis tuberosa, fibra de avena, extrusión, índice de expansión, densidad aparente

\section{Introducción}

The metabolic syndrome (SM) is defined as the set of cardiovascular risk factors constituted by central distribution obesity, Atherogenic dyslipidemia, glucose metabolism abnormalities and arterial hypertension, closely associated with insulin resistance $[3,10]$. The metabolic syndrome is a major and growing public health clinical challenge throughout the world following urbanization, surplus energy consumption, increased obesity and sedentary lifestyle habits [7]. 
Antioxidant compounds in health. Flavonoids are part of the polyphenol family and consist of a large group of watersoluble compounds, responsible for colorlessness such as yellow and red in flowers, fruits and leaves [4]. Flavonoids are now increasingly regarded as definite contributors to health benefits. Specifically, flavonoids have the ability to inhibit low density lipoprotein (LDL) oxidation, platelet aggregation and adhesion, as well as the enzymes involved in lipid and lipoprotein metabolism [2,6,14].

Oxalis tuberosa. The Oca secondly, in antioxidant content after mashua (Tropaeolum tuberosum) followed by potatoes and ulluco (Ullucus tuberosus). In addition, significant amounts of fructooligosaccharides have been found in oca $[5,8,9]$. For the edible part of the oca, per $100 \mathrm{~g}$ of fresh material, energy values $61 \mathrm{kcal} ; 1.0 \mathrm{~g}$ protein; fat $0.6 \mathrm{~g}$; fiber $1.0 \mathrm{~g}$ and carbohydrates 13.3 [11]. The OCA contains significant amounts of phenolic compounds. These provide important sensory properties to food and can also play an important role in the prevention of various diseases related to oxidative stress $[15,17]$.

Materials and methods. For the elaboration of the Oxalis tuberosa flour, the tuber of the city of Acaxochitlan, Hidalgo was obtained. Wheat semolina was used. The pasta was elaborated with a formulation of 50/50 elaborated by lamination process $[12,18]$. To which chemical analysis was carried out proximal by the official methods of the AOAC (1995). The antioxidant activity was measured by the DPPH method [4] and by the ABTS method [16]. The total phenolic content were determined using a modification of te Folin-Ciocalteu Following estándar method [16].

Animals. The experimental group consisted of 24 female Wistar rats purchased from the Bioterio of the Autonomous University of the state of Hidalgo and individually housed in controlled conditions and with ad libitum access to food and water. After rats were acclimatised for two weeks and had reached $160 \mathrm{~g}$ body weight, they were randomly divided into 5 experimental diet groups. The induction of the metabolic syndrome was with a high fructose drink giving $10 \%$ the first month and $20 \%$ to the second month.

Anthropometric measurements. The nutritional status of female rats was assessed by means of anthropometric parameters such as weight with a scale, abdominal circumference and length of nose - anus with a tape measure for determine the BMI.

Evaluation of serum metabolites. During the 8 weeks, serum glucose metabolites were evaluated with a TS Contour meter, the lipid profile of cholesterol and triglycerides were by means of a Accutrend Plus Monitor Sanguíneo.

Statistical analysis. The IBM SPSS Statistics statistical package was used. A ANOVA and for the comparison of means, the Tukey method $(P<0.05)$ was used.

Result and discussion

The data obtained from the proximal chemical analysis of the pasta enriched with Oxalis tuberose flour (Table 1). Analysis in which it can be observed that this pasta showed a good percentage of fiber $5.948 \pm 0.69$ as well as protein $10.31 \pm 0.07$. In a work by Vicente (2016) reported values of a native flour of Oxalis tuberosa with fiber of $2.19 \pm 0.04$ and protein $12.59 \pm 0.33$ so that respectively compared the results obtained from the paste in fiber are higher however the content of Protein is relatively higher than obtained.

Table 1. Nutritional information of pasta enriched with Oxalis tuberosa flour and control pasta.

\begin{tabular}{|lccccccc|}
\hline \multicolumn{1}{|c}{ PRODUCT } & $\begin{array}{c}\text { Energy } \\
(\mathrm{KCAL})\end{array}$ & $\begin{array}{c}\text { Humidity } \\
(\mathbf{g} / 100 \mathrm{~g})\end{array}$ & $\begin{array}{c}\text { Ashes } \\
(\mathbf{g} / 100 \mathrm{~g})\end{array}$ & $\begin{array}{c}\text { Protein } \\
(\mathbf{g} / 100 \mathrm{~g})\end{array}$ & $\begin{array}{c}\text { Fat } \\
(\mathbf{g} / 100 \mathrm{~g})\end{array}$ & $\begin{array}{c}\text { Fiber } \\
(\mathbf{g} / 100 \mathrm{~g})\end{array}$ & $\begin{array}{c}\text { Carbohydrate } \\
(\mathbf{g} / 100 \mathrm{~g})\end{array}$ \\
\hline $\begin{array}{l}\text { Pasta } \\
\text { enriched with } \\
\text { Oxalis }\end{array}$ & $334.2 \pm 1.36$ & $8.9 \pm 0.89$ & $2.5 \pm 0.03$ & $10.31 \pm 0.07$ & $1.04 \pm 0.19$ & $5.94 \pm 0.69$ & $70.87 \pm 0.24$ \\
\hline Pasta control & 173 & - & - & 6 & 1 & 2 & 35 \\
\hline
\end{tabular}

Antioxidant capacity. The results showed that the percentage content of inhibition by DPPH was $58.21 \%$ while Merendino et al. (2014) reported a percentage of inhibition of $60 \%$ in a paste with Tartary buckwheat so the difference between these with respect to their activity antioxidant measured by DPPH is minimal, with respect to the content of total phenols in its paste of $2.3 \mathrm{mg}$ of gallic acid / $\mathrm{mg}$ of sample while in the paste with Oxalis tuberosa has $1.46 \mathrm{mg}$ of gallic acid / $\mathrm{mg}$ of sample this author studied the antioxidant capacity of the pasta with Tartaria to evaluate the antihypotensive effect in an animal model.

In vivo studies

Biochemical parameters. Some biochemical markers of the metabolic syndrome were evaluated to compare and observe the effect of the antioxidant bioactive compounds of the enriched pasta with Oxalis tuberosa. In table 2 with respect to the biochemical values of final glucose, total cholesterol, C-VLDL, C-LDL and triglycerides within the induction groups, the IPOT group was the lowest. In a study by Qin \& Anderson (2012) similar results were obtained in which the antioxidant activity of the chokeberry extract was evaluated in rats fed a fructose-rich diet, with reduced values of glucose, plasma insulin, triglycerides, total colesterol and LDL-C.

Anthropometric parameters. In weight values in the last week no statistically significant differences were observed however the gain of weight in the IPOT group was lower compared to the other groups. The result can be seen reflected in the BMI, weight of visceral fat and abdominal circumference (Table 3). The IPOT group showed lower values in these parameters compared to the other groups with induction. 
Table 2. Lipid profile and uric acid in groups I, IPOT, IPC, CPOT and CPC.

\begin{tabular}{|c|c|c|c|c|c|}
\hline & $\begin{array}{l}\text { Induction } \\
\text { Group (I) }\end{array}$ & $\begin{array}{c}\text { Induction } \\
\text { Group Pasta } \\
\text { Oxalis } \\
\text { tuberosa } \\
\text { (IPOT) }\end{array}$ & $\begin{array}{l}\text { Induction } \\
\text { Group Control } \\
\text { Pasta } \\
\text { (IPC) }\end{array}$ & $\begin{array}{l}\text { Control group } \\
\text { Pasta Oxalis } \\
\text { tuberosa } \\
\text { (CPOT) }\end{array}$ & $\begin{array}{l}\text { Control } \\
\text { Pasta } \\
\text { Control } \\
\text { Group } \\
\text { (CPC) }\end{array}$ \\
\hline $\begin{array}{l}\text { FINAL GLUCOSE } \\
(\mathrm{mg} / \mathrm{dL})\end{array}$ & $103.6 \pm 14.8^{b}$ & $85.8 \pm 2.2 \mathrm{ab}$ & $100 \pm 14.1^{b}$ & $97.6 \pm 9.2^{b}$ & $75.7 \pm 6.1^{a}$ \\
\hline $\begin{array}{c}\text { FINAL } \\
\text { CHOLESTEROL } \\
(\mathrm{mg} / \mathrm{dL})\end{array}$ & $92.9 \pm 17.6$ & $70.1 \pm 5.0$ & $75.5 \pm 8.4$ & $67.95 \pm 13.6$ & $66.8 \pm 2.1$ \\
\hline VLDL (mg/dL) & $19.9 \pm 4.9$ & $18.5 \pm 4.6$ & $27.7 \pm 12.8$ & $36.4 \pm 2.5$ & $25.5 \pm .14$ \\
\hline LDL (mg/dL) & $41 \pm 18.3$ & $21 \pm 4.2$ & $19.5 \pm 4.9$ & $21.5 \pm 7.7$ & $19 \pm 2.8$ \\
\hline HDL (mg/dL) & $46.5 \pm 2.1$ & $45 \pm 8.4$ & $51.5 \pm 3.5$ & $42.5 \pm 4.9$ & $44 \pm 1.4$ \\
\hline $\begin{array}{l}\text { Final triglycerides } \\
\qquad(\mathrm{mg} / \mathrm{dL} \text { ) }\end{array}$ & $99.5 \pm 24.7$ & $92.5 \pm 23.3$ & $138.5 \pm 64.3$ & $182 \pm 12.7$ & $125.5 \pm 3.5$ \\
\hline
\end{tabular}

Table 3. Anthropometric parameters in groups I, IPOT, IPC, CPOT and CPC.

\begin{tabular}{|c|c|c|c|c|c|}
\hline & $\begin{array}{c}\text { Control } \\
\text { Pasta } \\
\text { Control } \\
\text { Group (CPC) }\end{array}$ & $\begin{array}{l}\text { Control group } \\
\text { Pasta Oxalis } \\
\text { tuberosa } \\
\text { (CPOT) }\end{array}$ & $\begin{array}{c}\text { Induction } \\
\text { Group Control } \\
\text { Pasta } \\
\text { (IPC) }\end{array}$ & $\begin{array}{c}\text { Induction } \\
\text { Group Pasta } \\
\text { Oxalis tuberosa } \\
\text { (IPOT) }\end{array}$ & $\begin{array}{l}\text { Induction Group } \\
\text { (I) }\end{array}$ \\
\hline $\begin{array}{l}\text { INITIAL WEIGHT } \\
\text { (g) }\end{array}$ & $154.7 \pm 10.4$ & $160.8 \pm 9.2$ & $157.8 \pm 12.6$ & $159.6 \pm 8.6$ & $161.0 \pm 14.2$ \\
\hline $\begin{array}{l}\text { FINAL WEIGHT } \\
\text { (g) }\end{array}$ & $216.2 \pm 25.19$ & $226.2 \pm 18.80$ & $238.8 \pm 18.32$ & $232.2 \pm 12.69$ & $235.8 \pm 18.59$ \\
\hline BMI $\left(\mathrm{g} / \mathrm{cm}^{2}\right)$ & $0.583 \pm 0.03^{a}$ & $0.588 \pm 0.42^{a b}$ & $0.627 \pm 0.42^{a b}$ & $0.605 \pm 0.44^{a b}$ & $0.667 \pm 0.46^{b}$ \\
\hline $\begin{array}{l}\text { ABDOMINAL } \\
\text { CIRCUMFERENC } \\
\text { E (cm) }\end{array}$ & $12 \pm 0.81^{\mathrm{ab}}$ & $11.8 \pm 0.44^{a b}$ & $12.8 \pm 0.83^{b}$ & $11.4 \pm 0.54^{a}$ & $12.8 \pm 0.83^{b}$ \\
\hline $\begin{array}{l}\text { VISCERAL FAT } \\
\text { (g) }\end{array}$ & $7 \pm 0.816^{a b}$ & $3.2 \pm 1.30^{\mathrm{a}}$ & $10.8 \pm 4.32^{b}$ & $9.0 \pm 3.76^{a b}$ & $11.8 \pm 3.50^{b}$ \\
\hline LIVER (g) & $7.40 \pm 0.65^{a}$ & $8.78 \pm 1.14^{a b}$ & $8.66 \pm 1.35^{\mathrm{ab}}$ & $8.90 \pm 0.65^{a b}$ & $10.28 \pm 1.04^{b}$ \\
\hline HEART $(\mathrm{g})$ & $0.91 \pm 0.12$ & $1.01 \pm 0.10$ & $1.04 \pm 0.08$ & $1.01 \pm 0.15$ & $1.01 \pm 0.69$ \\
\hline
\end{tabular}

\section{Conclusions}

The antioxidant properties and nutritional composition of the Oxalis tuberosa showed influence in managing low levels of glucose, total cholesterol, LDL cholesterol, cholesterol VLDL as well as triglycerides. They also had an influence on maintaining anthropometric values. So the enriched pasta with Oxalis tuberosa is a good food to attenuate some symptoms of the metabolic syndrome.

\section{Bibliography}

1. A.O.A.C. (1995). Official Method of Analysis. Association of official Analytical Chemist, 16th . Washington D.C. USA.

2. Basu, A., Rhone, M., \& T.J., L. (2010). Berries: emerging impact on cardiovascular. Nutrition Reviews, 68(3), 168-177.

3. Bello, B., Sánchez, G. A., Báez, E. G., Fernández, J., \& Achiong, F. (2013). Síndrome Metabólico: un problema de salud con múltiples definiciones. Revista Médica Electron, 34(2), 199-213.

4. Brand-Williams, W. C. (1995). Use of a free radical method to evaluate antioxidant activity. LWT - Food Science and Technology, 28, 25-30.

5. Bravo, L. (1998). Polyphenols: Chemistry, dietary sources, metabolism, and nutritional significance. Nutririon Reviews, 56, 317-33.

6. Campos, D., Noratto, G., Chirinos, R., \& Arbizu, C. (2006). Antioxidant capacity and secondary metabolites in four species of andean tuber crops: Native potato (Solanum sp.), mashua (Tropaeolum tuberosum Ruiz and 
Pavón), oca (Oxalis tuberosa Molina) and ullucu (Ullucus tuberosum). Journal Science Food Agriculture, 86, 1481-1488.

7. Chu, Y. F., \& Liu, R. H. (2005). Cranberries inhibit LDL oxidation and induce LDL receptor hepatocytes. Life Sciences, 77(15), 1892-1901.

8. Fernández, T. J. C. (2016). Síndrome Metabólico y Riesgo Cardiovascular. Revista CENIC Ciencias Biológicas, 47 (2), 106-119.

9. Flores, H. E., Walker, T. S., Guimaraes, R. L., \& H., B. P. (2003). Andean root and tuber crops: Underground rainbows. Hortic. Science, 38, 161-167.

10. Jiménez, M. E., Rossi, A., \& Sammán, N. (2015). .Health properties of oca (Oxalis tuberosa) and yacon (Smallanthus sonchifolius). Food \& Function, 27, 20-30.

11. Kunstmann, S. (2008). Síndrome Metabólico y Riesgo Cardiovascular. Revista Médica Clínica Condes, 19(1), 40-46.

12. León, M., Villacorta, M. Y., \& Pagador, S. E. (2011). Composición química de oca (Oxalis tuberosa), arracacha (Arracaccia xanthorriza) y tarwi (Lupinus mutabilis). Formulación de una mezcla base para productos alimenticios. Revista Venezolana de Ciencia y Tecnología de Alimentos.

13. Merendino, N., Romina, M., Costantini, L., \& A., M. (2014). A new "functional" pasta containing tartary buckwheat sprouts as an ingredient improves the oxidative status and normalizes some blood pressure parameters in spontaneously hypertensive rats. Food \& Function, 5, 1017-1026.

14. Qin, B., \& Anderson, R. (2012). An extract of chokeberry attenuates weight gain and modulates insulin, adipogenic and inflammatory signalling pathways in epididymal adipose tissue of rats fed a fructose-rich diet. Br J Nutr, 108, 581-587.

15. Reed, J. (2002). Cranberry flavonoids, atherosclerosis and cardiovascular health. Critical Reviews in Food Science and Nutrition, 52, 301-316.

16. Re, R., Pellegrinini, N., Proteggente, A., Panala, A., Yang, M., \& Rice-Evans, C. (1999). Antioxidant activity applyng an improved ABTS radical cation decoloration assay.Free radical. Biol. Med., 10, 1231-1237.

17. Ross, J. A., \& Kasum, C. M. (2002). Dietary flavanoids: Bioavailability, metabolic effects, and safety. Annual Review in Nutrition, 22, 19-34.

18. Singleton, V., \& Rossi, J. (1995). Colorimetry of total phenolics with phosphomolybdic-phosphotungstic acid reagents. American Journal of Enology and Viticulture, 16, 144-158.

19. Tsao, R., \& Deng, Z. (2004). Separation procedures for naturally occurring antioxidant phytochemicals. Journal Chromatography, 85-99.

20. Vicente, F. (2016). Efecto de la sustitución de sémola de trigo con harina de Oxalis tuberosa en las propiedades fisicoquímicas y reológicas de pastas. Tesis de Maestría UAEH. 